\title{
Combine Shot Penning (SP) and Ultrasonic Impact Treatment (UIT) for Soil Corrosion Buckling Strength Enhancement of AA 2014-T4
}

\author{
Hussain J. Mohamed Al-Alkawi ${ }^{1}$, Saad T. Faris ${ }^{2}$, Salam Nihad Naji ${ }^{3}$
}

\section{Authors Affiliations: \\ 1) Electromechanical Eng. \\ Dept., University of \\ Technology, Baghdad- \\ Iraq. \\ Alalkawi2012@yahoo.co \\ $\underline{\mathrm{m}}$ \\ 2) Mechanical Eng. Dept., \\ University of Diyala, \\ Diyala-Iraq. \\ prof- \\ drsaaddiab@yahoo.com \\ 3) Mechanical Eng. Dept., University of Diyala, Diyala, Iraq. \\ s.nuhad21@gmail.com}

\section{Paper History:}

Received: $1^{\text {st Jan. } 2020}$

Revised: $21^{\text {st Jan. } 2020}$

Accepted: $16^{\text {th }}$ March 2020

\begin{abstract}
The aim of this work is to investigate the effect of soil corrosion on the critical buckling load of circular columns made of 2014-T4 aluminum alloy. In this work, 24 specimens were used and buried in the soil for 120 days. The samples divided into two groups (12 columns with corrosion before shot penning (SP) and ultrasonic impact treatment (UIT), and 12 columns with corrosion after combined surface treatments $(\mathrm{SP}+\mathrm{UIT}))$. The experimental1results revealed1 that the corrosion negatively1affects the mechanical properties1of the material, and the1reduction percentage (R\%) for1ultimate tensile strength (UTS) and1yield strength (YS) was $(1.95 \%$ and $4.57 \%)$ respectively. After combined surface treatments (SP+UIT) for the corroded columns, the ultimate1tensile strength (UTS) and yield1strength (YS) were improved with (2.42\%, and 2.87\%) respectively. Perry-Robertson, Rankine, and ANSYS were used to estimate the critical buckling load (Pcr) and compare it with the experimental results. Rankine and Perry's formulas have been achieved a good agreement with the experimental without and with (1.5) factor of safety respectively. While ANSYS gave satisfactory prediction with a safety factor of (2.2, and 2.7) and (1.9, and 2.7) for long and intermediate columns before and after (SP+UIP) respectively.
\end{abstract}

Keywords: 2014-T4 aluminum Alloy, Shot Penning (SP) and Ultrasonic Impact Treatment (UIT), Buckling Column, Perry and Rankine Theories, Soil Corrosion, Factor of Safety.

$$
\begin{aligned}
& \text { لمجع بين الضرب بالكرات (SP) والموجات فوق الصوتية (UIT) لتحسين مقاومة سبيكة } \\
& \text { المنيوم (T4-2014) المتعرضة لتأكل التربة } \\
& \text { حسن جاسم العلكاوي، سعد ذياب فارس ، سلام نهاد ناجي }
\end{aligned}
$$

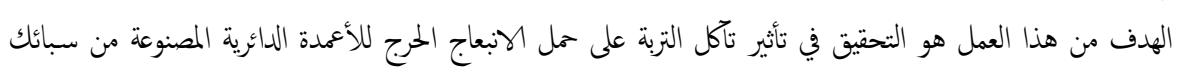

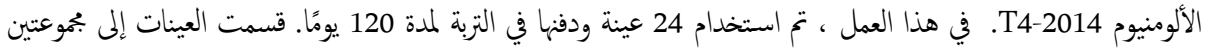

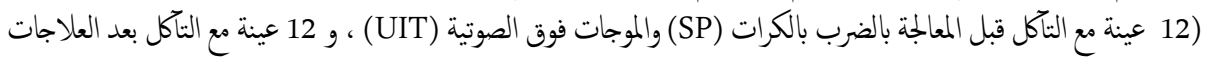

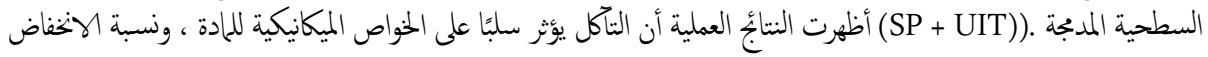

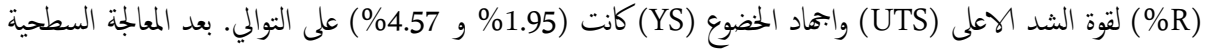

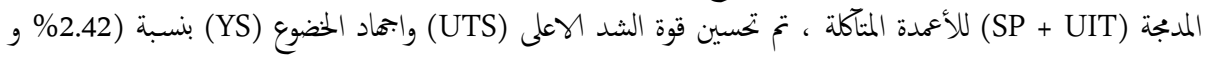

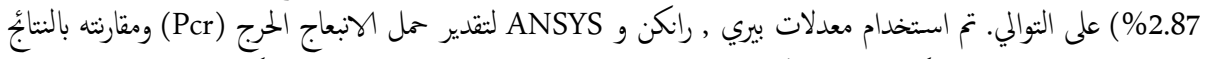

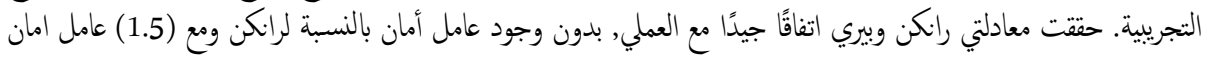

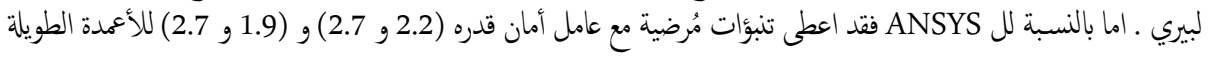

$$
\begin{aligned}
& \text { والمتوسطة قبل وبعد (SP + UIT) على التوالي. }
\end{aligned}
$$

NJES is an open access Journal with ISSN 2521-9154 and eISSN 2521-9162

This work is licensed under a Creative Commons Attribution-NonCommercial 4.0 International License 
NJES 23(2)144-152, 2020

Al-Alkawi et al.

\section{Nomenclature}

\begin{tabular}{|c|c|c|}
\hline Symbols & Description & Unit \\
\hline YS & Yield strength & $(\mathrm{MPa})$ \\
\hline UTS & Ultimate tensile strength & $(\mathrm{MPa})$ \\
\hline $\mathrm{P}_{\mathrm{cr}}$ & Critical buckling load & N \\
\hline $\mathrm{L}$ & Total column length & $(\mathrm{mm})$ \\
\hline $\mathrm{L}_{\mathrm{e}}$ & Effective column length & $(\mathrm{mm})$ \\
\hline $\mathrm{I}$ & Moment of inertia & $\left(\mathrm{mm}^{4}\right)$ \\
\hline $\mathrm{A}$ & Cross sectional area & $\left(\mathrm{mm}^{2}\right)$ \\
\hline $\mathrm{D}$ & Diameter of column & $\left(\mathrm{mm}^{2}\right)$ \\
\hline $\mathrm{E}$ & Modulus of elasticity & $(\mathrm{GPa})$ \\
\hline $\mathrm{r}$ & Radius of gyration & $(\mathrm{mm})$ \\
\hline$\delta$ in & Initial column deflection & $(\mathrm{mm})$ \\
\hline$\delta \mathrm{cr}$ & Critical deflection & $(\mathrm{mm})$ \\
\hline $\mathrm{S} . \mathrm{R}$ & Slenderness ratio & \\
\hline $\mathrm{C}_{\mathrm{c}}$ & Column constant & \\
\hline $\mathrm{SF}$ & Factor of Safety & \\
\hline & & \\
\hline
\end{tabular}

\section{Introduction}

The failures due to the instability phenomena can happen suddenly and may cause the whole construction to collapse. So, it is very important for engineers to have good information about this phenomenon. The buckling of the columns is one of the common models of instability phenomenon [1]. Structures failure due to the buckling phenomenon is still of interest to the engineers and researchers. Study the buckling behavior of the column is an important step to understanding and guess the reliability of the constructions that have more complex designs [2]. The column is defined as a structural member that carries a compressive load at one end, the cross-sectional dimensions are considerably smaller than the length that will be the orientation in which the load is applied. The buckling phenomenon occurs when a column is subjected1to an axial compressive load and deflect because the loading is big enough. The critical buckling load of the column is defined as the maximum axial load that the column can support before it tends failure [3]. Structures can fail when a structural member or the whole construction reaches yield or ultimate strength, override the maximum deflection, or when a fracture of members or collapse occurs. Buckling is a wide term that describes several of the mechanical behaviors [4]. Buckling can be defined as the bending of the structural members under an axial compressive load. The columns are slender members that carry the axial load. The column may fail because of the instability of the structures when the compressive load excessive and this phenomenon called buckling. The buckling problem of the columns is a very serious issue. Therefore, neglect this effect may lead to catastrophic results or unjustified safety factors [5]. Corrosion can be defined as the deterioration of the material because of the reaction with its environment. This can influence negatively the metal because of the loss of a cross-sectional area, it can ruin the metal due1to hydrogen embrittlement, or cracking of a material due to sunlight exposure. The corrosion is preponderant in offshore and marine structures because of the fact that seawater is an aggressive corrosive environment [6].

Oszvald and Dunai, 2012 [7], studied the effect of the corrosion on the buckling behavior of corroded1stee angle members. The influence of the corrosion location and the loss of the cross-section area were studied by experimental investigation. The samples had been exposed to three types' of corrosion uniform, pitting, and local corrosion. The behavior of the steel angle members was estimated and evaluated. The corrosion resistance was reduced due to corrosion.

Jatav and Datta, 2014 [8], studied the column shape optimization which is subjected to safe and unsafe loads. They found that the unsafe loads occurred at the column subjected to a corrosion environment.

Hussein F.A., 2018 [9], studied the effect of the soil corrosion on the intermediate and long columns made from aluminum alloy 6061-T4. 27 specimens were used with two different corrosion time (30 and 60 days). Increasing corrosion time affects negatively on1the mechanical properties1 of the material and reduce the1critical buckling load. The reduction in critical buckling load was $(2.5 \%$ and $5.7 \%$ ) for 30 and 60 days for long corroded columns and (1.69\% and 4.2\%) for the intermediate corroded columns. He found that the prediction of the Perry formula has a good agreement with the experimental work with a factor of safety of (1.2).

AL-Khazraji A. N. et al 2014 [10], the aim of this survey is to determine the best enhancement of the buckling behavior of steel alloy (CK35) due to shot peening surface treatment under compression and combined loading. The results showed that the dynamic buckling behavior and the mechanical properties had been improved due to shot peening. The best improvement of the dynamic buckling load was obtained at 25 minutes of shot peening time. Because of utilized the shot peening treatment, some types of columns changed from long to intermediate based on Euler and Johnson formula.

Literature surveys showed that the exposure to a corrosive media and the surface treatments have a large effect on the life and resistance of structures. The present work is concentrated on the effect of the soil corrosion on the metal, and the influence of surface treatments (shot penning (SP) and ultrasonic impact treatment (UIT)) together on the column surface with utilize three formulas (Perry, Rankine, and ANSYS) in order to compare the results with the experimental work.

\section{Experimental Work \\ 2.1. Chemical Composition}

Chemical composition analysis of the Al-alloy used in this work was conducted at Company State for Engineering Rehabilitation and Inspection (SIER). The results had compared with the ASM [11] as shown in table (1). 
Table (1): Chemical composition of 2014-T4 aluminum alloy

\begin{tabular}{|c|c|c|c|c|c|c|c|c|c|}
\hline $\begin{array}{c}\text { 2014-T4 } \\
\text { Alumin } \\
\text { um } \\
\text { alloy }\end{array}$ & Al & $\mathbf{C r}$ & $\mathbf{C u}$ & $\mathbf{F e}$ & $\mathbf{M g}$ & $\mathbf{M n}$ & $\mathbf{S i}$ & $\mathbf{T i}$ & $\mathbf{Z n}$ \\
\hline $\begin{array}{c}\text { ASM } \\
\text { [11] }\end{array}$ & Bal. & $\begin{array}{c}\max \\
0.1\end{array}$ & $\begin{array}{c}3.9- \\
5\end{array}$ & $\begin{array}{c}\mathrm{Max} \\
0.7\end{array}$ & $\begin{array}{c}0.2- \\
0.8\end{array}$ & $\begin{array}{c}0.4- \\
1.2\end{array}$ & $\begin{array}{c}0.5- \\
1.2\end{array}$ & $\begin{array}{c}\text { Max } \\
0.15\end{array}$ & $\begin{array}{c}\text { Max } \\
0.25\end{array}$ \\
\hline Experi. & Bal. & 0.08 & 4.1 & 0.36 & 0.52 & 0.96 & 0.8 & 0.11 & 0.19 \\
\hline
\end{tabular}

\subsection{Tensile Test}

The tensile testing was conducted by using the (WDW-200E) device as shown in Fig. (1), at the University of Technology, Materials Engineering Department. The mechanical properties of (2014-T4 Al-alloy) were compared with ASM [11]. The tensile test specimen were made according to the specifications of ASTM [12] as shown in figure (2) (all dimensions in $\mathrm{mm}$ ).
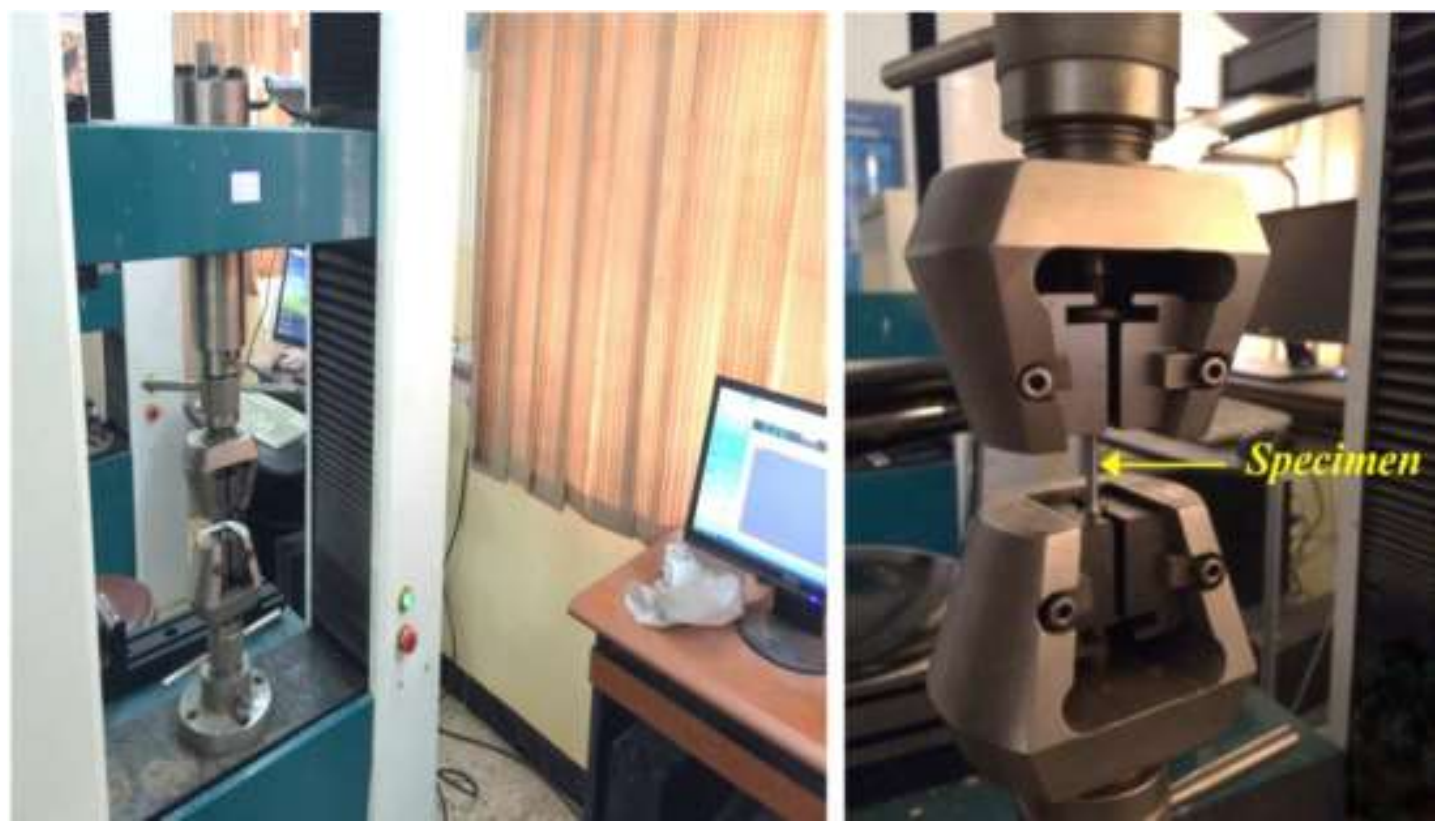

Figure (1): Tensile test device WDW-200E

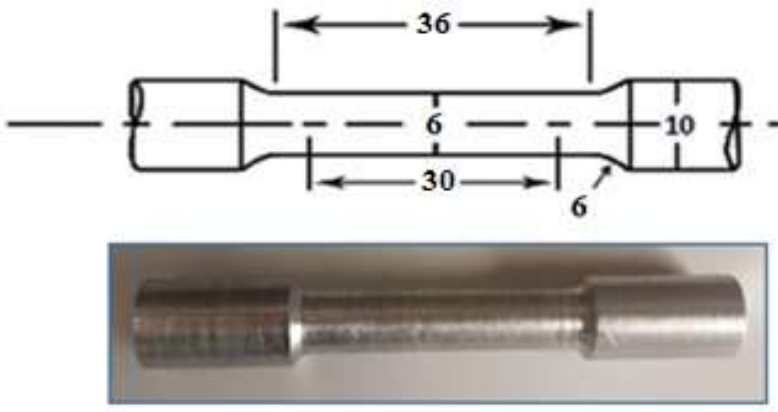

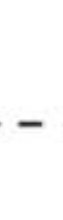

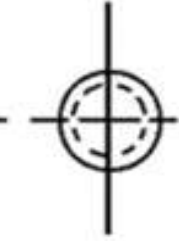

Figure (2): Tensile test specimen according to the ASTM [12]

The mechanical properties are listed in table (2), and it's the average of three samples:

Table (2): Mechanical properties of aluminum alloy (2014-T4) before and after (SP+UIT)

\begin{tabular}{|c|c|c|c|}
\hline $\begin{array}{c}\text { 2014-T4 } \\
\text { Aluminum } \\
\text { alloy }\end{array}$ & $\begin{array}{c}\text { UTS } \\
\text { (MPa) }\end{array}$ & $\begin{array}{c}\text { YS } \\
\text { (MPa) }\end{array}$ & $\begin{array}{c}\text { E } \\
\text { (GPa) }\end{array}$ \\
\cline { 2 - 4 } & \multicolumn{3}{|c|}{ Before (SP+UIT) } \\
\hline $\begin{array}{c}\text { Standard } \\
\text { ASM[9] }\end{array}$ & 425 & 290 & 73 \\
\hline $\begin{array}{c}\text { Dry columns } \\
\text { (without } \\
\text { corrosion) }\end{array}$ & 410 & 284 & 71 \\
\hline
\end{tabular}

\begin{tabular}{|c|c|c|c|}
\hline $\begin{array}{c}\text { Columns with } \\
\text { Soil Corrosion }\end{array}$ & 402 & 271 & 69.5 \\
\hline \multicolumn{3}{|c|}{ After (SP+UIT) } \\
\hline $\begin{array}{c}\text { Dry columns } \\
\text { (without } \\
\text { corrosion) }\end{array}$ & 422 & 293 & 73 \\
\hline $\begin{array}{c}\text { Columns with } \\
\text { soil corrosion }\end{array}$ & 412 & 279 & 70 \\
\hline
\end{tabular}

SP: Shot Peening, UIT: Ultrasonic Impact Treatment

\subsection{Dimensions of Buckling Specimens}

Table (3) illustrates the dimensions of the 2014-T4 Alalloy specimens used in this work. 
Table (3): Dimensions of the buckling specimens (AA 2014-T4)

\begin{tabular}{|c|c|c|c|c|c|c|}
\hline $\mathbf{N O}$. & $\begin{array}{c}\mathrm{L}_{\mathrm{T}} \\
\mathbf{( m m})\end{array}$ & $\begin{array}{c}\mathrm{L}_{\mathrm{e}} \\
(\mathbf{m m})\end{array}$ & $\begin{array}{c}\mathrm{D} \\
(\mathbf{m m})\end{array}$ & $\mathrm{S} . \mathrm{R}$ & $\mathrm{C}_{\mathrm{c}}$ & $\begin{array}{c}\text { Type of } \\
\text { column }\end{array}$ \\
\hline $\mathbf{1}$ & 500 & 350 & 10 & 140 & 70.21 & long \\
\hline $\mathbf{2}$ & 500 & 350 & 8 & 175 & 70.85 & long \\
\hline $\mathbf{3}$ & 500 & 350 & 6 & 233.333 & 71.11 & long \\
\hline $\mathbf{4}$ & 400 & 280 & 10 & 112 & 70.21 & long \\
\hline $\mathbf{5}$ & 400 & 280 & 8 & 140 & 70.85 & long \\
\hline $\mathbf{6}$ & 400 & 280 & 6 & 186.66 & 71.11 & long \\
\hline $\mathbf{7}$ & 300 & 210 & 10 & 84 & 70.21 & long \\
\hline $\mathbf{8}$ & 300 & 210 & 8 & 105 & 70.85 & long \\
\hline $\mathbf{9}$ & 300 & 210 & 6 & 140 & 71.11 & long \\
\hline $\mathbf{1 0}$ & 200 & 140 & 10 & 56 & 70.21 & intermediate \\
\hline
\end{tabular}

\begin{tabular}{|c|c|c|c|c|c|c|}
\hline 11 & 200 & 140 & 8 & 70 & 70.85 & intermediate \\
\hline 12 & 200 & 140 & 6 & 93.33 & 71.11 & long \\
\hline
\end{tabular}

S.R: Slenderness Ratio, Cc: Column Constant

$$
\mathrm{S} . \mathrm{R}=\mathrm{L}_{\mathrm{e}} / \mathrm{r}_{\min } \quad, \quad \mathrm{C}_{\mathrm{c}}=\sqrt{\frac{2 \pi^{2} E}{\sigma_{y}}}
$$

If the slenderness ratio (SR) is greater than the column constant $\left(\mathrm{C}_{\mathrm{c}}\right)$, then the column is long, while if the slenderness ratio (SR) is smaller than the column constant $\left(\mathrm{C}_{\mathrm{c}}\right)$, then the column called intermediate.

\subsection{Buckling Test}

AA 2014 -T4 columns had been tested by using the test rig device as shown in fig (3), which is able to buckle the specimens by applying an axial compressive load with two rotating speeds (17 and $34 \mathrm{rpm}$ ), in the current work $17 \mathrm{rpm}$ will be adopted. The test had been conducted at the University of Technology, Electromechanical Engineering Department.

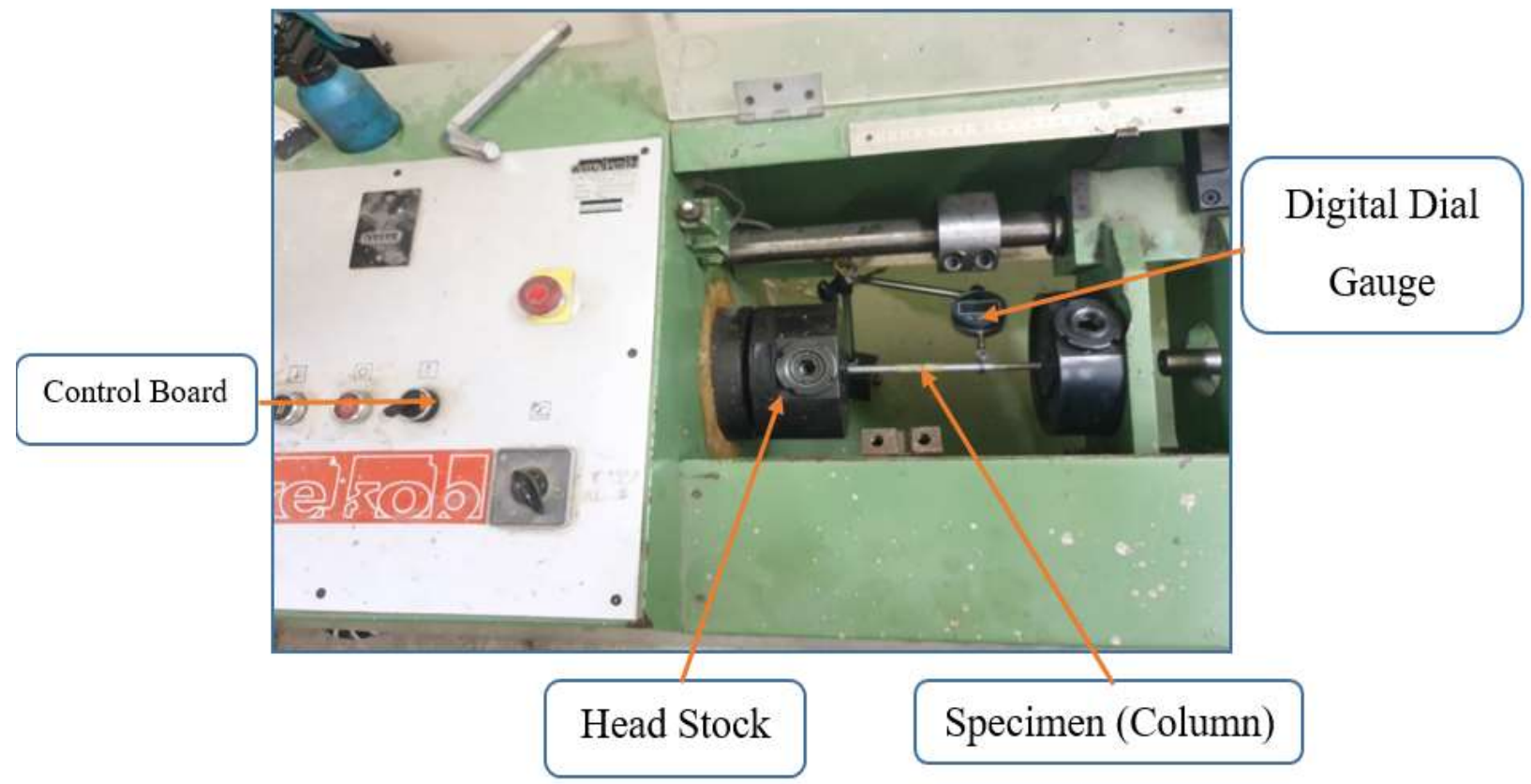

Figure (3): Test-rig machine

Experimental Buckling Results for Corroded and non-corroded Columns

Tables (4) and (5) shows the results for long and intermediate columns (2014-T4 aluminum alloy) that have been tested under increasing dynamic buckling load and the reduction percentage ( $\mathrm{R} \%$ ) due to soil corrosion before surface treatment by $(\mathrm{SP}+\mathrm{UIT})$.

Table (4): Results for long columns under increasing buckling load before (SP+UIT)

\begin{tabular}{|c|c|c|c|c|c|c|c|c|c|c|c|}
\hline NO. & $\begin{array}{c}L \\
\mathbf{m m}\end{array}$ & $\begin{array}{c}L_{e f f} \\
\mathbf{m m}\end{array}$ & $\begin{array}{l}\text { Dia. } \\
\mathbf{m m}\end{array}$ & $\begin{array}{l}\text { Area } \\
\mathbf{m m} 2\end{array}$ & S.R. & $C c$ & $\begin{array}{l}P_{c r} \\
\boldsymbol{N}\end{array}$ & $\sigma(M P a)$ & $\begin{array}{c}\text { din } \\
\mathbf{m m}\end{array}$ & $\begin{array}{c}\delta c r \\
\mathbf{m m}\end{array}$ & $\begin{array}{l}\mathrm{R} \\
\%\end{array}$ \\
\hline $1(D)$ & 500 & 350 & 10 & 78.5 & 140 & 70.21 & 1570 & 20 & 0.5 & 5.6 & \\
\hline $2(S C)$ & 500 & 350 & 10 & 78.5 & 140 & 71.11 & 1513 & 19.27 & 0.55 & 5.8 & 3.63 \\
\hline $3(D)$ & 500 & 350 & 8 & 50.24 & 175 & 70.21 & 803.8 & 16 & 0.22 & 5.4 & \\
\hline $4(S C)$ & 500 & 350 & 8 & 50.24 & 175 & 71.11 & 763.6 & 15.2 & 0.84 & 5.8 & 5 \\
\hline $5(D)$ & 500 & 350 & 6 & 28.26 & 233.33 & 70.21 & 226.1 & 8.001 & 0.3 & 5.38 & \\
\hline $6(S C)$ & 500 & 350 & 6 & 28.26 & 233.33 & 71.11 & 203.2 & 7.19 & 0.8 & 5.6 & 10.1 \\
\hline
\end{tabular}


NJES 23(2)144-152, 2020

Al-Alkawi et al.

\begin{tabular}{|c|c|c|c|c|c|c|c|c|c|c|c|}
\hline $7(\boldsymbol{D})$ & 400 & 280 & 10 & 78.5 & 112 & 70.21 & 2867 & 36.52 & 0.48 & 4.3 & \\
\hline $8(S C)$ & 400 & 280 & 10 & 78.5 & 112 & 71.11 & 2632 & 33.53 & 0.81 & 4.89 & 8.2 \\
\hline $9(D)$ & 400 & 280 & 8 & 50.24 & 140 & 70.21 & 1005 & 20 & 0.26 & 4.5 & \\
\hline $10(S C)$ & 400 & 280 & 8 & 50.24 & 140 & 71.11 & 979.6 & 19.5 & 0.52 & 4.05 & 2.53 \\
\hline $11(D)$ & 400 & 280 & 6 & 28.26 & 186.67 & 70.21 & 367.4 & 13 & 0.08 & 4.6 & \\
\hline $12(S C)$ & 400 & 280 & 6 & 28.26 & 186.67 & 71.11 & 336.3 & 11.9 & 0.1 & 4.4 & 8.46 \\
\hline $13(D)$ & 300 & 210 & 10 & 78.5 & 84 & 70.21 & 4659 & 59.35 & 0.59 & 3.2 & \\
\hline $14(S C)$ & 300 & 210 & 10 & 78.5 & 84 & 71.11 & 4584 & 58.39 & 0.3 & 3.4 & 1.61 \\
\hline $15(D)$ & 300 & 210 & 8 & 50.24 & 105 & 70.21 & 2161 & 43.01 & 0.27 & 3.18 & \\
\hline $16(S C)$ & 300 & 210 & 8 & 50.24 & 105 & 71.11 & 2018 & 40.17 & 0.29 & 3.23 & 6.62 \\
\hline $17(D)$ & 300 & 210 & 6 & 28.26 & 140 & 70.21 & 608.7 & 21.54 & 0.28 & 3.3 & \\
\hline $18(S C)$ & 300 & 210 & 6 & 28.26 & 140 & 71.11 & 571.7 & 20.23 & 0.8 & 3.4 & 6.08 \\
\hline $19(D)$ & 200 & 140 & 6 & 28.26 & 93.333 & 70.21 & 1465.2 & 51.85 & 0.24 & 2.5 & \\
\hline $20(S C)$ & 200 & 140 & 6 & 28.26 & 93.333 & 71.11 & 1394.3 & 49.34 & 0.44 & 2.33 & 4.84 \\
\hline
\end{tabular}

D: Dry, SC: Soil Corrosion, R\%: Reduction Percentage

Reduction percentage was calculated by the equation below:

$\mathrm{R} \%=\frac{\operatorname{Pcr}(D)-P c r}{\operatorname{Pcr}(D)}$

Table (5): Results for intermediate columns under increasing buckling load before (SP+UIT)

\begin{tabular}{|c|c|c|c|c|c|c|c|c|c|c|c|}
\hline No.1 & $\begin{array}{c}L \\
\mathbf{m m}\end{array}$ & $\begin{array}{c}L_{e f f} \\
\mathbf{m m}\end{array}$ & $\begin{array}{l}\text { Dia. } \\
\mathbf{m m}\end{array}$ & $\begin{array}{l}\text { Area } \\
\mathbf{m m} 2\end{array}$ & S.R. & $C c$ & $\begin{array}{l}P_{c r} \\
\boldsymbol{N}\end{array}$ & $\sigma(M P a)$ & $\begin{array}{c}\delta \text { in } \\
\mathbf{m m}\end{array}$ & $\begin{array}{c}\delta c r \\
\mathbf{m m}\end{array}$ & $\begin{array}{l}\mathrm{R} \\
\% \\
\end{array}$ \\
\hline $28(D)$ & 200 & 140 & 10 & 78.5 & 56 & 70.21 & 6673 & 85.01 & 0.5 & 2.03 & \\
\hline $30(S C)$ & 200 & 140 & 10 & 78.5 & 56 & 71.11 & 6555 & 83.5 & 0.62 & 2.1 & 1.77 \\
\hline $31(D)$ & 200 & 140 & 8 & 50.24 & 70 & 70.21 & 3165 & 63 & 0.48 & 2.6 & \\
\hline $33(S C)$ & 200 & 140 & 8 & 50.24 & 70 & 71.11 & 3014 & 59.99 & 0.23 & 2.01 & 4.77 \\
\hline
\end{tabular}

From tables (4) and (5), it is observed that the critical buckling load for long and intermediate columns decreased due to soil corrosion.

\subsection{Surface Treatment}

The mechanical properties of the material can be improved by using surface treatment techniques, in this study shot peening (SP) and ultrasonic impact treatment (UIT) had been utilized.

\subsection{Ultrasonic Impact Treatment (UIT)}

The properties of the 2014-T4 AA were enhancement by using Ultrasonic impact treatment (UIT) device, which includes two portions (handheld and generator) as shown in the figures (4) and (5), and the specifications of the UIT device are listed in the table (4).

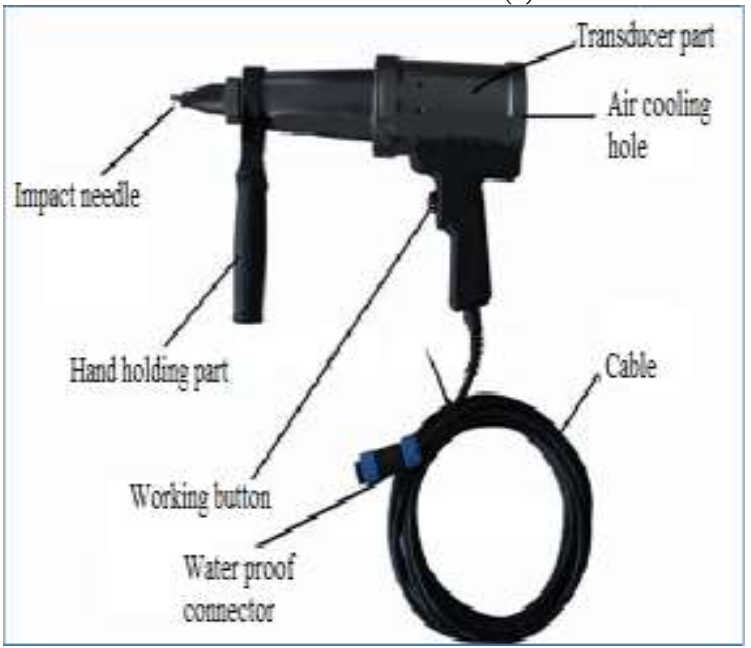

Figure (4): Handheld part of UIT device

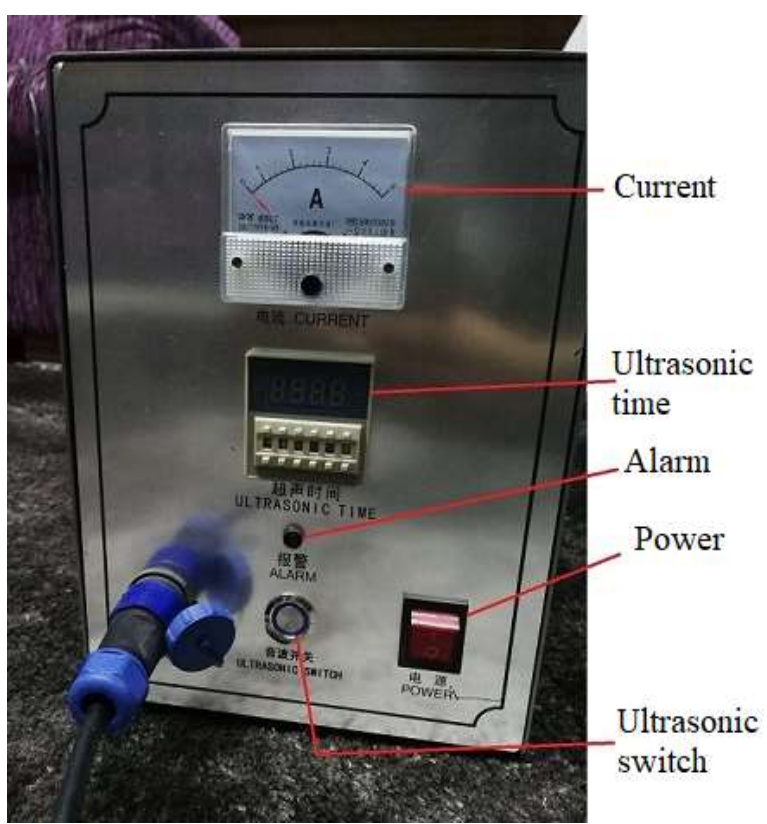

Figure (5): Power part of UIT device

Table (4): Specifications of the UIT device [13]

\begin{tabular}{|l|c|}
\hline \multicolumn{1}{|c|}{ Items } & Values \\
\hline Major power supply & $220 \mathrm{~V}, 50 \mathrm{HZ}$ \\
\hline Common max. working current & $4.5 \mathrm{~A}$ \\
\hline DC fuse wire diameter & $4.55 \mathrm{~A}$ \\
\hline Max. pulse power & $1000 \mathrm{~W}$ \\
\hline Matched transducer & $20 \mathrm{KHz}$ \\
\hline Recommend max. power working & $500 \mathrm{~W}$ \\
\hline Impact needle & 4 sets, Ø $3 \times 25 \mathrm{~mm}$ \\
\hline
\end{tabular}




\subsection{Shot Peening (SP)}

Shot peening is a cold working operation where the worked metal is peened with small balls to introduce compressive residual stress and work hardening or alternatively to remove surface layers [14]. The shot peening process is impacting a surface of the material with a shot (metallic balls, ceramic particles, glass) with enough force to produce plastic deformation
[15]. Shot penning also used to improve the mechanical properties of the metal, which is conducted by using a centrifugal wheel system. The shot penning device used in this work is (STB-OB) as shown in figure (6), and the specifications are listed in the table (5). The operating speed of the machine is 1435 r.p.m, and the wheel diameter is $590 \mathrm{~mm}$. The shot flow rate is varied to get various shot peening intensities.

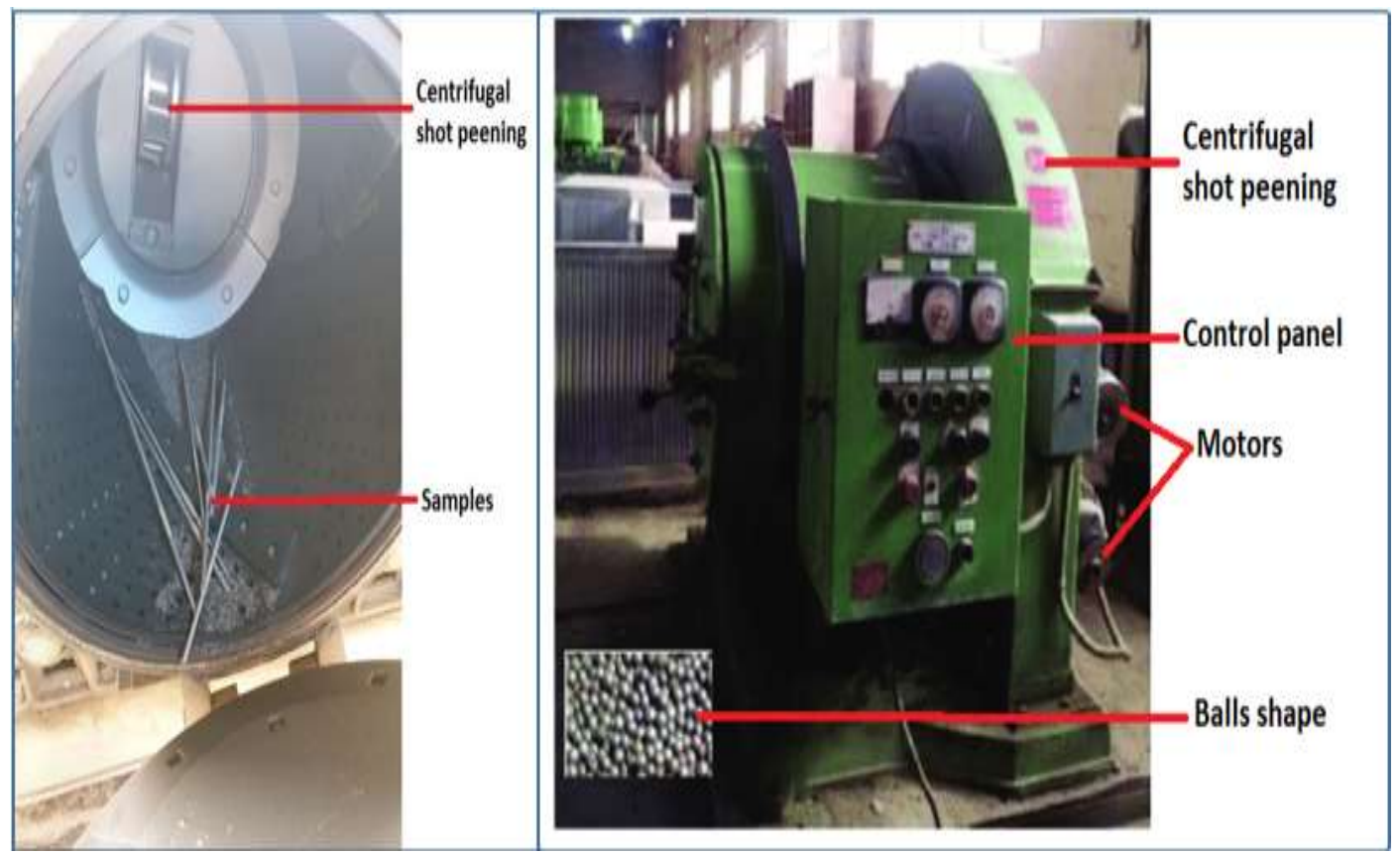

Figure (7): Shot peening device

Table (5): Specifications of Shot Penning Machine

\begin{tabular}{|c|c|c|c|}
\hline Items & Quant. & Unit & Remark \\
\hline Ball size & 0.6 & $\mathrm{~mm}$ & \\
\hline Sphere material & ------ & ------ & Cast Steel \\
\hline Rockwell hardness & $(48-50)$ & HRC & \\
\hline Pressure & 12 & $\mathrm{bar}$ & \\
\hline Speed & 40 & $\mathrm{~m} / \mathrm{sec}$ & \\
\hline $\begin{array}{c}\text { Distance from nozzle } \\
\text { to specimen }\end{array}$ & 10 & $\mathrm{~cm}$ & \\
\hline
\end{tabular}

\section{Buckling Theories}

Columns are split into two groups (long and intermediate) according to the slenderness ratio (SR) and the transition slenderness ratio $\left(\mathrm{C}_{\mathrm{c}}\right)$. If $(\mathrm{SR})$ is greater than $\left(\mathrm{C}_{\mathrm{c}}\right)$, then the column is long, and if (SR) is smaller than $\left(\mathrm{C}_{\mathrm{c}}\right)$, then the column is intermediate [16].

\section{Slenderness Ratio (SR)}

$\mathrm{SR}$ is define as the ratio of the effective length $\left(\mathrm{L}_{\mathrm{e}}\right)$ of column to the radius of gyration:

$\mathrm{S} . \mathrm{R}=\mathrm{KL} / \mathrm{r}_{\min }=\mathrm{L}_{\mathrm{e}} / \mathrm{r}_{\min }$

Where

$\mathrm{K}$ : end-fixity factor

L: total length of column

$\mathrm{L}_{\mathrm{e}}$ : effective length

$r_{\text {min }}$ smallest radius of gyration

$$
r=\sqrt{\frac{I}{A}}
$$

I: moment of inertia

A: cross-sectional area

\section{Column Constant $\left(\mathrm{C}_{\mathrm{c}}\right)$}

$$
\mathrm{C}_{\mathrm{c}}=\sqrt{\frac{2 \pi^{2} E}{\sigma_{y}}}
$$

Where

E: modulus of elasticity of the column material $\sigma_{y}$ : yield stress of column material

\section{Perry-Robertson Formula}

Perry-Robertson formula proof based on the assumptions that any fault in the member, through a material or eccentricity of loading, can be allowed by giving an initial curvature for the strut. For ease of calculations, it assumed to be a cosine curve, in spite of the actual shape assumed has a tiny effect on the results [17].

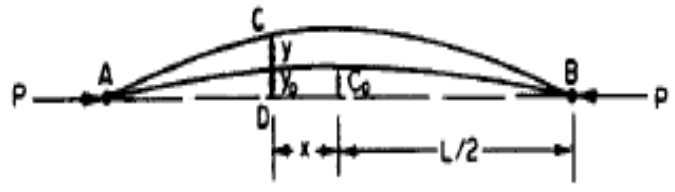

Figure (8): column with initial curvature [14] 
$\mathrm{P}=A\left[\frac{\sigma_{\mathrm{y}}+(1+\eta) \sigma_{\mathrm{e}}}{2}-\sqrt{\left(\frac{\sigma_{\mathrm{y}}+(1+\eta) \sigma_{\mathrm{e}}}{2}\right)^{2}-\sigma_{\mathrm{y}} \sigma_{\mathrm{e}}}\right] \ldots$

Where

$\eta$ : a constant depending on the material.

For a brittle material, $\eta=0.015 \mathrm{~L} / \mathrm{k}$

For a ductile material, $\mathrm{\eta}=0.3\left(\frac{L_{e}}{100 r}\right)^{2}$

$\mathrm{L}_{\mathrm{e}}$ : effect length of pinned end strut

$=0.7 \mathrm{~L}$ of fixed ends strut

$=2.0 \mathrm{~L}$ of strut with one end fixed,

$\mathrm{r}$ : radius of gyration

$\sigma_{\mathrm{y}}:$ yield stress

$\sigma_{\mathrm{e}}$ : Euler stress

A: cross sectional area of column

Rankine or Rankine-Gordon Formula

Rankine formula is applicable for the columns, ranging from very long to short ones, but it does not give reliable results. Rankine, after many of the experiments, gave the empirical formula for columns as shown below:

$\mathrm{P}_{\mathrm{R}}=\frac{\sigma y A}{1+a\left(\frac{L}{K}\right)^{2}}$

Where

A: cross-sectional area

$\sigma_{\mathrm{y}}:$ is the yield stress in compression
L: total length of column

$\mathrm{K}$ : end-fixity factor

a: Rankine's constant $=\sigma y / \pi^{2} E$

E: Young of modulus

ANSYS

The finite element modeling (FEM) of the problem is an important step to achieve precise results. For FEM a computer program has been utilized called ANSYS. Beam element is utilized in the modeling and the FE mesh of the column is modeled using suitable nodes and elements depending on the length and cross-section of the column with sizing and bias factor [5]. ANSYS provides two modeling methods which are solid modeling and direct modeling. In general, solid modeling is more suitable for large or complex models that allow working with a relatively small number of data items as well as many other advantages [18].

\section{Results and Discussions}

\subsection{Mechanical Properties}

The mechanical properties of the specimens had been improved due to the surface treatments (SP+UIT), table (6) shows the values of ultimate tensile strength (UTS) and yield strength (YS) before and after (SP+UIT):

Table (6): Illustrates improvement percentage in UTS \& YS due to (SP+UIT)

\begin{tabular}{|c|c|c|c|c|c|}
\hline \multirow{2}{*}{\multicolumn{2}{|c|}{ Property }} & \multicolumn{2}{|c|}{$\begin{array}{c}\text { Dry columns } \\
\text { (without corrosion) }\end{array}$} & \multicolumn{2}{|c|}{$\begin{array}{l}\text { Columns with soil } \\
\text { corrosion }\end{array}$} \\
\hline & & $\begin{array}{c}\text { Before } \\
(S P+U I T)\end{array}$ & $\begin{array}{c}\text { After } \\
(S P+U I T)\end{array}$ & $\begin{array}{c}\text { Before } \\
(S P+U I T)\end{array}$ & $\begin{array}{c}\text { After } \\
(S P+U I T)\end{array}$ \\
\hline \multicolumn{2}{|l|}{ UTS MPa } & 410 & 422 & 402 & 412 \\
\hline \multicolumn{2}{|l|}{ YS MPa } & 284 & 293 & 271 & 279 \\
\hline \multirow{2}{*}{ improvement Percentage \% } & UTS & \multicolumn{2}{|c|}{2.84} & \multicolumn{2}{|c|}{2.42} \\
\hline & $Y S$ & \multicolumn{2}{|c|}{3.07} & \multicolumn{2}{|c|}{2.87} \\
\hline
\end{tabular}

Table (6) shows that after applying (SP+UIT) on the specimens UTS and YS were improved by $(2.84 \%$ and $3.07 \%)$ and $(2.42 \%$ and $2.87 \%)$ for dry and soil corrosion columns respectively.

Buckling Results
Tables (7) and (8) illustrate a comparison between the critical load $\left(\mathrm{P}_{\mathrm{cr}}\right)$ of (Experimental, Perry, Rankine, and ANSYS) of the corroded samples before and after (SP+UIT) for the long and intermediate columns with and without safety factor.

Table (7): Comparison between the results of (Perry, Rankine, and ANSYS) with the Experimental for long and intermediate columns before (SP+UIT)

\begin{tabular}{|c|c|c|c|c|c|c|c|c|c|}
\hline $\begin{array}{c}S p . \\
\text { No. }\end{array}$ & $\begin{array}{c}L \\
(\mathrm{~mm})\end{array}$ & $\begin{array}{c}L_{e f f} \\
(\mathbf{m m})\end{array}$ & $\begin{array}{c}D \\
(\mathbf{m m})\end{array}$ & $\begin{array}{c}P_{c r} \\
\text { Exper. } \\
(\mathbf{N})\end{array}$ & $\begin{array}{c}P_{c r} \\
\text { Perry } \\
(\mathbf{N})\end{array}$ & $\begin{array}{c}P_{c r} \\
\text { Perry } \\
(\mathbf{N})\end{array}$ & $\begin{array}{c}P_{c r} \\
\text { Rankine } \\
(\mathbf{N})\end{array}$ & $\begin{array}{c}P_{c r} \\
A N S Y S \\
(\mathbf{N})\end{array}$ & $\begin{array}{c}P_{c r} \\
A N S Y S \\
(\mathbf{N})\end{array}$ \\
\hline \multicolumn{10}{|c|}{ Long Columns } \\
\hline \multicolumn{4}{|l|}{$S F$} & 1 & without & 1.5 & without & without & 2.2 \\
\hline 1 & 500 & 350 & 10 & 1513 & 2175 & 1450 & 1265 & 2745 & 1248 \\
\hline 2 & 500 & 350 & 8 & 763.6 & 897.6 & 598.4 & 529.4 & 1125 & 511 \\
\hline 3 & 500 & 350 & 6 & 203.2 & 285.6 & 190.4 & 170.4 & 356.1 & 162 \\
\hline 4 & 400 & 280 & 10 & 2632 & 3202 & 2135 & 1912 & 4285 & 1948 \\
\hline 5 & 400 & 280 & 8 & 979.6 & 1330 & 886.7 & 809.5 & 1757 & 799 \\
\hline
\end{tabular}


NJES 23(2)144-152, 2020

Al-Alkawi et al.

\begin{tabular}{|c|c|c|c|c|c|c|c|c|c|}
\hline 6 & 400 & 280 & 6 & 336.3 & 425.1 & 283.4 & 263 & 556.3 & 253 \\
\hline 7 & 300 & 210 & 10 & 4584 & 5098 & 3398 & 3178 & 7602 & 3455 \\
\hline 8 & 300 & 210 & 8 & 2018 & 2154 & 1436 & 1375 & 3119 & 1418 \\
\hline 9 & 300 & 210 & 6 & 571.7 & 696.9 & 464.6 & 455.3 & 988.2 & 449 \\
\hline 10 & 200 & 140 & 6 & 1394.3 & 1327 & 884.4 & 953.6 & 2118 & 1008 \\
\hline \multicolumn{10}{|c|}{ Intermediate Columns } \\
\hline \multicolumn{4}{|l|}{$S F$} & 1 & without & 1.5 & without & without & 2.7 \\
\hline 11 & 200 & 140 & 10 & 6554.7 & 8816 & 5877 & 6025 & 17004 & 6297 \\
\hline 12 & 200 & 140 & 8 & 3014.4 & 3941 & 2627 & 2748 & 6991 & 2589 \\
\hline
\end{tabular}

Table (8): Comparison between the results of (Perry, Rankine, and ANSYS) with the experimental for long and intermediate columns after (SP+UIT)

\begin{tabular}{|c|c|c|c|c|c|c|c|c|c|}
\hline $\begin{array}{c}S p . \\
\text { No. }\end{array}$ & $\begin{array}{c}L \\
(\mathrm{~mm})\end{array}$ & $\begin{array}{c}L_{e f f} \\
(\mathbf{m m})\end{array}$ & $\begin{array}{c}D \\
(\mathrm{~mm})\end{array}$ & $\begin{array}{c}P_{c r} \\
\text { Exper. } \\
(\mathbf{N})\end{array}$ & $\begin{array}{c}P_{c r} \\
\text { Perry } \\
(\mathbf{N})\end{array}$ & $\begin{array}{c}P_{c r} \\
\text { Perry } \\
(\mathbf{N})\end{array}$ & $\begin{array}{c}P_{c r} \\
\text { Rankine } \\
(\mathbf{N})\end{array}$ & $\begin{array}{c}P_{c r} \\
A N S Y S \\
(\mathbf{N})\end{array}$ & $\begin{array}{c}P_{c r} \\
A N S Y S \\
\text { (N) }\end{array}$ \\
\hline \multicolumn{10}{|c|}{ Long Columns } \\
\hline \multicolumn{4}{|l|}{$S F$} & 1 & without & 1.5 & without & without & 1.9 \\
\hline 1 & 500 & 350 & 10 & 1670 & 2209 & 1472 & 1276.9 & 2765 & 1455 \\
\hline 2 & 500 & 350 & 8 & 803.6 & 910.9 & 607 & 534.02 & 1133 & 596.4 \\
\hline 3 & 500 & 350 & 6 & 225.1 & 289.7 & 193 & 171.78 & 358.7 & 188.8 \\
\hline 4 & 400 & 280 & 10 & 2775 & 3259 & 2173 & 1932.9 & 4316 & 2271 \\
\hline 5 & 400 & 280 & 8 & 1405 & 1352 & 902 & 817.21 & 1769 & 931.3 \\
\hline 6 & 400 & 280 & 6 & 462.6 & 432 & 288 & 265.22 & 560.3 & 294.9 \\
\hline 7 & 300 & 210 & 10 & 4708 & 5211 & 3474 & 3219.1 & 7656 & 4030 \\
\hline 8 & 300 & 210 & 8 & 2032 & 2198 & 1465 & 1390.9 & 3141 & 1653 \\
\hline 9 & 300 & 210 & 6 & 582.6 & 710.1 & 473 & 459.68 & 995.3 & 523.8 \\
\hline 10 & 200 & 140 & 6 & 1407 & 1358.7 & 905.8 & 965.18 & 2235 & 1176 \\
\hline \multicolumn{10}{|c|}{ Intermediate Columns } \\
\hline \multicolumn{4}{|l|}{$S F$} & 1 & without & 1.5 & without & without & 2.7 \\
\hline 11 & 200 & 140 & 10 & 6659 & 9043 & 6029 & 6135.6 & 17126 & 6343 \\
\hline 12 & 200 & 140 & 8 & 3040 & 4039 & 2693 & 2789.5 & 7042 & 2608 \\
\hline
\end{tabular}

From tables (7) and (8), it is clear that soil corrosion negatively affects the ultimate tensile strength (YTS) and yield strength (YS), and this leads to reduce critical buckling load $\left(\mathrm{P}_{\mathrm{cr}}\right)$ of the aluminum alloy specimens. This finding is in good agreement with what was found by Hussien J. M. Al-alkawi et al [19]. It is also illustrated that Perry and ANSYS gave not satisfactory predictions, but with a factor of safety, a good agreement achieves with the experimental and this also what was found by Shawthab A. J. [20].

\section{Conclusions}

The combination of (SP+UIT) techniques can be effectively utilized for improving the mechanical and buckling properties of 2014-T4 aluminum alloy. The improvement percentage of UTS and YS of the corroded columns was $(2.84 \%$ and $3.07 \%)$ and $(2.42 \%$ and 2.87 $\%$ ) for dry and soil corrosion columns respectively due to (SP+UIT) techniques. Benefits obtained by combination of (SP+UIT) techniques are the results of the compressive residual stresses. The critical buckling loads $\left(\mathrm{P}_{\mathrm{cr}}\right)$ where reduced due to soil corrosion (SC). The maximum reduction percentage $(\mathrm{R} \%$ ) was $10.1 \%$ and $4.77 \%$ for long and intermediate columns respectively.

\section{References}

[1] H. Kevin, A Study of Initial Curvature and Braces Influence On a Column's Load Bearing Capacity, MSc. Thesis, Division of Structural Engineering, September, 2014.

[2] A. Ziółkowski, S. Imiełowski, "Buckling and Postbuckling Behaviour of Prismatic Aluminum Columns Submitted to a Series of Compressive Loads", Experimental Mechanics, vol.51, No.8, 2011, pp.1335-1345.

[3] Arnold M, Euler Buckling of column, MSc. Thesis, University of Surrey, April, 2013.

[4] Charles E. Riley, Elastic Buckling Loads of Slender Columns with Variable Cross Section by the Newmark Method, MSc. Thesis, Colorado state University, Department of Civil Engineering, May, 2003.

[5] Mehmet Avcar, "Elastic buckling of steel columns under axial compression", Amerian Journal of Civil Engineering, Vol.2, No.3, 2014, pp.102 - 108.

[6] Adhithya Plato Sidharth, "Effect of pitting corrosion on ultimate strength and buckling strength of plate A review ", Digest Journal of Nanomaterials and Biostructures. Vol. 4, No. 4, 2009, pp. 783-788.

[7] Katalin Oszvald and László Dunai,"Effect of corrosion on the buckling of steel angle 
members - experimental study", periodica polytechnic 56/2 (2012) 175-183.

[8] Jatav S.K., Datta P.K.," Shape Optimization of Damaged Columns Subjected to Conservative and Non-Conservative Forces", International Journal of Aeronautical and Space Sciences, Vol. 15, No. 1, March, 2014, pp. 20-31.

[9] Hussein F. Ajaj,'Buckling-Corrosion Interaction of Al Alloy (6061-T4) Columns under Increasing Loads and Detection using Wireless Control System", M.Sc. Thesis, University of Technology, Electromechanical Engineering Department, 2018.

[10] AL-Khazraji A. N., Al-Alkawi H. J. M, and Essam Z. Fadhel," Determination the Optimum Shot Peening Time for Improving the Buckling Behavior of Medium Carbon Steel”, Eng. \& Tech. Journal , Vol.32, No.3, 2014.

[11] American Society for Metals (ASM Handbook), "Properties and Selection: Nonferrous Alloys and Special-Purpose Materials", Vol. 2, 10th ED, 1992.

[12] American Society for Testing and Materials, ASTM B557M-14, July, 2014.

[13] Hangzhou Create Ultrasonic Technology Co., Ltd., Ultrasonic prestressing force impact treatment system (Operation instruction).
[14] K. Tosha, J. Lu2, B. Guelorget and E. Nagashima, "Effect of shot peening and grit blasting on surface integrity: Influence on residual stresses", International Scientific Committee for Shot Peening, 2005, pp. 400-405.

[15] Hetram, Lakhwinder Singh, and Hari Om," Shot Peening Effects on Material Properties", International Journal for Innovative Research in Science \& Technology, Vol. 1, Issue 12, May 2015.

[16] Robert L. Mott and Joseph A. Untener, Applied Strength of Materials, $6^{\text {th }}$ ED, Taylor \& Francis Group, LLC, 2017.

[17] E. J. Hearn, Mechanics of materials, 3th ED, University of Warwick, United Kingdom, 2001.

[18] Ahmed M. Salih, Buckling of Stiffened and Unstiffened Laminated Composite Plates Under Combined Loading, MSc. Thesis, University of Baghdad, Mechanical Engineering Department, 2013.

[19] Husain .J. M. Al-alkawi, Abduljabbar O. H., and Hussein Fadhil A. ," Corrosion - buckling interaction of 6061-t4 al alloy fixed - pinned columns - experimental study", The Iraqi Journal For Mechanical And Material Engineering, Vol.18, No1, March 2018.

[20] Shawthab Ali Jaber ," Evaluation the Buckling Behavior for 304 Stainless Steel Under Effect of Buckling and Corrosion Interaction", Msc. Thesis, University of Mustansiriayah, 2018. 